\title{
Basal Insulin Treatment in Type 2 Diabetes
}

\author{
Maka S. Hedrington, M.D., Lindsay Pulliam, B.S., and Stephen N. Davis, MBBS, FRCP, FACP
}

\begin{abstract}
Insulin glargine is the first 24-h recombinant DNA insulin analog introduced to the market. Substitution of glycine for asparagine and addition of two arginine residues raise the isoelectric point of insulin glargine and result in microprecipitates, delaying absorption from subcutaneous tissue. This delayed absorption result in fairly flat 24-h insulin concentration profiles with no discernible peak. Large, multicenter, randomized, controlled trials in patients with type 2 diabetes show that although NPH insulin and insulin glargine are equally effective in lowering glycosylated hemoglobin (A1c) and fasting blood glucose, there is a clear advantage of insulin glargine over NPH insulin in reducing nocturnal and overall hypoglycemia. Lower risk of hypoglycemia with glargine was also consistently demonstrated by trials comparing insulin glargine and premixed analog insulins. These studies also showed greater reduction in A1c with twice-daily premixed insulins compared with glargine, when insulin glargine was administered without mealtime insulin coverage. Insulin glargine was also compared with another insulin analog, insulin detemir. Trials showed that both insulin analogs are equally effective in lowering A1c and have comparable risk of hypoglycemia. Trials comparing insulin glargine with glucagon-like peptide-1 agonists showed comparable significant reductions in A1c with both regimens. Insulin glargine is well tolerated, has low immunogenicity, reduced risks for acute myocardial infarction, and a lower risk of hypoglycemia compared with NPH insulin in individuals with type 2 diabetes.
\end{abstract}

\section{Introduction}

L ATEST ESTIMATES REVEAL that 25.4 million Americans have diabetes mellitus (DM), with up to $95 \%$ of those having type $2 \mathrm{DM}^{1}$ Additionally, close to 50 million individuals have prediabetes, with an annual conversion rate to diabetes close to $15 \%$.

Type 2 DM is typically characterized by insulin deficiency, coupled with insulin resistance. Continuing declining $\beta$-cell function is a hallmark of the disease leading to progressive insulinopenia and persistent carbohydrate and lipid abnormalities. Following dietary and weight loss interventions, early pharmacologic treatment for type 2 DM has traditionally been oral medications. However, because of decreasing $\beta$-cell function, insulin replacement therapy becomes a necessity in many type 2 DM patients. Exogenous insulin treatment for DM provided one of the major breakthroughs in modern medical science.

Soon after the discovery of regular insulin in the 1920s attempts were made to prolong the in vivo action of the molecule. Additions of zinc and or protamine produced several differing formulations (lente, ultralente, neutral protamine Hagedorn [NPH], protamine zinc insulins) that could be used once or even multiple times per day. However, these preparations produced noticeable peaks in activity and had a duration of action either too short (or too long) to be used as a basal insulin (i.e., to simulate the physiologic constitutive release of inter- and postprandial insulin).

Insulin analogs are a more recent addition to the insulin market. They are modified versions of human insulin that primarily change the duration of absorption of the molecule to optimize glucose control throughout the day. Long-acting insulin analogs, such as glargine (Lantus ${ }^{\circledR}$, Sanofi-Aventis, Paris, France) ${ }^{2}$ and detemir (Levemir ${ }^{\circledR}$, Novo-Nordisk, Bagsvaerd, Denmark), ${ }^{3}$ have a longer absorption time than NPH or regular human insulin and are designed for use as basal glucose control with once- or twice-daily treatment.

\section{Insulin Glargine}

Insulin glargine was the first 24-h insulin analog introduced to the market. It is approved for use in adults and children with type $1 \mathrm{DM}$ and adults only with type $2 \mathrm{DM}^{2}$

Glargine is a human insulin analog, made by recombinant DNA that is altered from normal human insulin by a substitution of glycine for asparagine at position A21 and the addition of two arginine residues to the B-chain at the C-terminus. Insulin glargine injection solution has a $\mathrm{pH}$ of 4 , which neutralizes to $\mathrm{pH} 7$ postinjection. The arginine residue additions raise the isoelectric point of insulin glargine and result in microprecipitates postinjection, thereby delaying absorption from subcutaneous tissue. Unlike many other 
insulins, glargine's pharmacokinetic and pharmacodynamic effects do not appear to be influenced by anatomic injection. Additionally, glargine's action does not appear to be influenced by exercise, even after injection into an exercising limb. The mechanism of action for insulin glargine is the same as human insulin: namely, to inhibit hepatic glucose production, stimulate glucose uptake in peripheral tissues (mainly skeletal muscle), and additionally inhibit lipolysis and proteolysis. Insulin glargine is recommended for subcutaneous administration only. For patients with type $2 \mathrm{DM}$ who are not on insulin therapy, the recommended starting dosage is either 10 units or 0.2 units $/ \mathrm{kg}$ once per day with adjustments made as needed. ${ }^{2}$

\section{Pharmacodynamics and Pharmacokinetics}

Following subcutaneous injection insulin glargine degrades into two additional metabolites. M1 is formed by the cleavage of the two C-terminal arginines on the B-chain. M2 includes the cleavages of M1 with the additional loss of the threonine next in sequence. These metabolites are present both at the injection site and systemically (in a 50:50 ratio with insulin glargine). ${ }^{4}$

The duration of action for insulin glargine has been repeatedly measured at or very near $24 \mathrm{~h}$. Luzio et al. ${ }^{5}$ investigated 12 men with type $2 \mathrm{DM}$ and determined the duration of action to be at least $24 \mathrm{~h}$ at a dose of $0.5 \mathrm{U} / \mathrm{kg}$. This is consistent with a study by Wang et al. ${ }^{6}$ of 20 obese insulin-resistant men and women with type $2 \mathrm{DM}$ who were less well metabolically controlled (glycosylated hemoglobin [A1c] $8.3 \pm 0.6 \%)$ and also showed insulin action at $24 \mathrm{~h}$ with doses of $0.5,1.0,1.5$, and $2.0 \mathrm{U} / \mathrm{kg}$.

Two studies using the Biostator ${ }^{\circledR}$ glucose infusion system (Miles Laboratories, Inc., Elkhart, IN) also found the duration of action to be close to $24 \mathrm{~h}$ in individuals with type $2 \mathrm{DM}$ and healthy individuals. Hompesch et al. ${ }^{7}$ measured a duration of $23.8 \mathrm{~h}$ following a dose of $0.8 \mathrm{U} / \mathrm{kg}$ insulin glargine in type 2 DM patients, whereas in 12 healthy men given a dose of $0.4 \mathrm{U} / \mathrm{kg}$ insulin glargine had a duration of action greater than $24 \mathrm{~h}$.

The glucose infusion rate increase only modestly with higher doses of insulin glargine. ${ }^{5,6}$ Wang et al. ${ }^{6}$ and Luzio et $\mathrm{al}^{5}$ found mean values of $2.6 \pm 0.9 \mathrm{mg} / \mathrm{kg} / \mathrm{min}$ at approximately $11 \mathrm{~h}$ and $2.0 \pm 0.2 \mathrm{mg} / \mathrm{kg} / \mathrm{min}$ at approximately $12 \mathrm{~h}$, respectively, following a dose of $0.5 \mathrm{U} / \mathrm{kg}$, whereas Hompesch et al. ${ }^{7}$ found a mean of $1.8 \pm 1.6 \mathrm{mg} / \mathrm{kg} / \mathrm{min}$ at around $9.5 \mathrm{~h}$ at a dose of $0.8 \mathrm{U} / \mathrm{kg}$. These modest "peak" glucose infusion rates (remembering that basal endogenous glucose production is $\sim 2.0 \mathrm{mg} / \mathrm{kg} / \mathrm{min}$ ) at high pharmacologic doses of glargine underscore the low hypoglycemic potential of the molecule.

The 24-h insulin concentration profiles during the glucose clamps in type 2 diabetes patients were also fairly flat, with no discernible peak. ${ }^{6-8}$ Maximum concentrations increased with higher doses but reached a plateau of mean insulin concentrations approximately $40 \mu \mathrm{IU} / \mathrm{mL}$ following injections of 1.0-2.0 U/kg. ${ }^{6}$ The time to reach maximum insulin levels ranged between 8 and 12 h. $^{7-9}$

Wang et al. ${ }^{6}$ demonstrated that doses of insulin glargine ranging from $0.5 \mathrm{U} / \mathrm{kg}$ to $2.0 \mathrm{U} / \mathrm{kg}$ inhibited C-peptide concentrations throughout clamps, indicating suppression of endogenous insulin secretion by glargine at these levels. In- sulin glargine has also been found to have a relatively hepatospecific action. Wang et al. $^{6}$ also demonstrated that suppression of endogenous glucose production to be significant and dose dependent during 24-h glucose clamp studies. However, the rate of glucose disappearance was not significantly different at any dose compared with a placebo. Thus insulin glargine has a relatively greater ability to suppress endogenous glucose production compared with stimulating glucose uptake. This physiologic effect is also important in potentially limiting hypoglycemia.

Insulin glargine measurement in plasma and serum samples presents some methodological problems due to its structural similarity to human insulin. Detection of insulin glargine and its two circulating metabolites may be performed by gas chromatography-mass spectrometry. This highly specialized technique is only available in a limited number of research laboratories. Therefore measurement is performed using immunoassays, either radioimmunoassay or enzyme-linked immunosorbent assay, which detect human insulin and insulin glargine. The degree of cross-reactivity between human insulin and glargine, which can range from $50 \%{ }^{9}$ to $180 \%,{ }^{4,5}$ would influence how well the assay reflects insulin glargine's true plasma or serum concentration and requires calibration adjustments with a glargine standard. ${ }^{4}$ In addition, the results of these assays would include contributions from endogenous insulin, which would also need to be subtracted from total values in order to determine the concentrations of glargine and any circulating metabolites. ${ }^{8}$

\section{Clinical Efficacy, Safety, and Tolerability}

The clinical efficacy, safety, and tolerability of insulin glargine have been evaluated and compared with other modified insulins in numerous clinical studies (see also Bolli et al. $^{10}$ in this supplement).

\section{Glargine Versus NPH (Table 1)}

$\mathrm{NPH}$ insulin is absorbed quickly from subcutaneous tissue with a pronounced peak of action at $4-5 \mathrm{~h}$ and duration of 14$17 \mathrm{~h}$. Depending on the injected dose, peak action can be associated with significant decreases in blood glucose levels and a risk for hypoglycemia. Bedtime NPH insulin injection thus can increase the risk of hypoglycemia during the night (2-4 a.m.). Fear of hypoglycemia often leads to poor compliance and consequently failure to achieve the desired target A1c level. In fact, with the occurrence of hypoglycemia, strategies to reduce the risk of this complication are implemented that can take priority over good glycemic control.

Thus in order to achieve tight metabolic control (and prevent microvascular complications of diabetes) there is an important clinical need for a basal insulin preparation that can simulate endogenous physiologic insulin release. The ideal basal insulin preparation would restrain endogenous glucose production and lipolysis without having peaked effects to cause hypoglycemia.

Numerous large, multicenter, randomized, controlled trials have compared NPH insulin and insulin glargine in patients with type 2 DM. These studies have ranged in duration from 4 weeks to 5 years. ${ }^{11-20}$ Baseline characteristics of the individuals studied have ranged from 27 to $35 \mathrm{~kg} / \mathrm{m}^{2}$ for body mass index, 55 to 62 years for age, and $8.3 \%$ to $9.7 \%$ for A1c. In most studies insulin was given once daily at bedtime, although one 
Table 1. Randomized Trials Comparing Insulin Glargine with Neutral Protamine Hagedorn Insulin in Patients with Type 2 Diabetes Mellitus

\begin{tabular}{|c|c|c|c|c|c|c|c|c|c|c|c|}
\hline \multirow[b]{2}{*}{ Study } & \multirow[b]{2}{*}{$\begin{array}{l}\text { Duration } \\
\text { (weeks) }\end{array}$} & \multirow[b]{2}{*}{$\begin{array}{l}\text { Basal } \\
\text { insulin }\end{array}$} & \multirow[b]{2}{*}{$\mathrm{n}$} & \multirow[b]{2}{*}{$\begin{array}{c}\text { Mean } \\
\text { daily dose }\end{array}$} & \multirow{2}{*}{$\begin{array}{c}\text { Baseline } \\
\text { A1c } \\
(\%)\end{array}$} & \multirow{2}{*}{$\begin{array}{c}\text { A1c } \\
\text { change } \\
\text { from } \\
\text { baseline } \\
(\%)\end{array}$} & \multicolumn{2}{|c|}{$\begin{array}{l}\text { Hypoglycemic } \\
\text { episodes }\end{array}$} & \multicolumn{2}{|c|}{$\begin{array}{c}\text { Nocturnal hypoglycemic } \\
\text { episodes }\end{array}$} & \multirow{2}{*}{$\begin{array}{l}\text { Weight } \\
\text { gain } \\
(\mathrm{kg})\end{array}$} \\
\hline & & & & & & & $\begin{array}{c}\% \text { of } \\
\text { patients }\end{array}$ & $\begin{array}{l}\text { Events per } \\
\text { patient-year }\end{array}$ & $\begin{array}{c}\% \text { of } \\
\text { patients }\end{array}$ & $\begin{array}{l}\text { Events per } \\
\text { patient-year }\end{array}$ & \\
\hline \multirow[t]{2}{*}{ Yki-Järvinen et al. ${ }^{11}$} & 52 & IG & 214 & $0.27 \mathrm{U} / \mathrm{kg}$ & 9.1 & $\downarrow 0.8$ & $33^{*}$ & & $9.9^{* *}$ & & $\uparrow 2.6$ \\
\hline & & $\mathrm{NPH}$ & 208 & $0.25 \mathrm{U} / \mathrm{kg}$ & 8.9 & $\downarrow 0.7$ & 50.7 & & 24 & & $\uparrow 2.3$ \\
\hline \multirow[t]{2}{*}{ Rosenstock et al. ${ }^{12}$} & 28 & $\mathrm{IG}$ & 259 & $0.75 \mathrm{U} / \mathrm{kg}$ & 8.6 & $\downarrow 0.4$ & 61.4 & & $26.5^{*}$ & & $\uparrow 0.4^{* *}$ \\
\hline & & $\mathrm{NPH}$ & 259 & $0.75 \mathrm{U} / \mathrm{kg}$ & 8.5 & $\downarrow 0.6$ & 66.8 & & 35.5 & & $\uparrow 1.4$ \\
\hline \multirow{2}{*}{$\begin{array}{l}\text { Yki-Järvinen et al., } \\
\text { LANMET }\end{array}$} & 36 & IG & 61 & $0.69 \mathrm{U} / \mathrm{kg}$ & 9.5 & $\downarrow 2.4$ & & 5.4 & & & $\uparrow 2.6$ \\
\hline & & $\mathrm{NPH}$ & 49 & $0.66 \mathrm{U} / \mathrm{kg}$ & 9.6 & $\downarrow 2.4$ & & 8 & & & $\uparrow 3.5$ \\
\hline \multirow[t]{2}{*}{ Riddle et al. ${ }^{14}$} & 24 & IG & 367 & $0.48 \mathrm{U} / \mathrm{kg}$ & 8.6 & $\downarrow 1.6$ & & $13.9^{*}$ & & $4^{* *}$ & $\uparrow 3$ \\
\hline & & $\mathrm{NPH}$ & 389 & $0.42 \mathrm{U} / \mathrm{kg}$ & 8.6 & $\downarrow 1.6$ & & 17.7 & & 6.9 & $\uparrow 2.8$ \\
\hline \multirow[t]{2}{*}{ Eliaschewitz et al. ${ }^{15}$} & 24 & IG & 2313 & $32.6 \mathrm{U} /$ day & 9.1 & $\downarrow 1.4$ & $52.8^{*}$ & $5^{*}$ & $20.4^{* * *}$ & $1.1^{*}$ & \\
\hline & & $\mathrm{NPH}$ & 2503 & $31.2 \mathrm{U} /$ day & 9.2 & $\downarrow 1.4$ & 62.8 & 7.2 & 34.8 & 3.1 & \\
\hline \multirow[t]{3}{*}{ Fritsche et al. ${ }^{16}$} & 28 & $\mathrm{IGm}$ & 236 & $40 \mathrm{U} /$ day & 9.1 & $\downarrow 1.2^{* *}$ & 74 & & $17^{* *}$ & & $\uparrow 3.9$ \\
\hline & & $\mathrm{IGb}$ & 227 & $39 \mathrm{U} /$ day & 9.1 & $\downarrow 1^{\dagger}$ & 68 & & $23^{* *}$ & & $\uparrow 3.7$ \\
\hline & & $\mathrm{NPH}$ & 232 & $37 \mathrm{U} /$ day & 9.1 & $\downarrow 0.8$ & 75 & & 38 & & $\uparrow 2.9$ \\
\hline \multirow{2}{*}{$\begin{array}{l}\text { HOE 901/2004 Study } \\
\text { Investigators Group }^{17}\end{array}$} & 4 & IG & 64 & $0.17 \mathrm{U} / \mathrm{kg}$ & 9.7 & $\downarrow 0.8$ & 18.8 & & $6.3^{*}$ & & $\uparrow 0.3$ \\
\hline & & $\mathrm{NPH}$ & 68 & $0.15 \mathrm{U} / \mathrm{kg}$ & 9.5 & $\downarrow 0.8$ & 32.4 & & 19.1 & & $\uparrow 0.7$ \\
\hline \multirow[t]{2}{*}{ Massi Benedetti et al. ${ }^{18}$} & 52 & $\mathrm{IG}$ & 289 & & 9 & $\downarrow 0.5$ & 35 & & $12^{*}$ & & $\uparrow 2$ \\
\hline & & $\mathrm{NPH}$ & 281 & & 8.9 & $\downarrow 0.4$ & 41 & & 24 & & $\uparrow 1.9$ \\
\hline \multirow[t]{2}{*}{ Fonseca et al. ${ }^{19}$} & 28 & IG & 523 & $36.4 \mathrm{U} /$ day & 8.4 & $\downarrow 0.4$ & $46^{*}$ & & 15 & & $\uparrow 0.4^{* *}$ \\
\hline & & $\mathrm{NPH}$ & 483 & $30.2 \mathrm{U} / \mathrm{day}$ & 8.4 & $\downarrow 0.5$ & 60 & & 27 & & $\uparrow 1.4$ \\
\hline \multirow[t]{2}{*}{ Rosenstock et al. ${ }^{20}$} & 5 years & IG & 5158 & 88.59 U/day & 8.4 & $\downarrow 0.5^{*}$ & 73.9 & & 56.1 & & $\uparrow 3.7$ \\
\hline & & $\mathrm{NPH}$ & 5099 & $91.8 \mathrm{U} /$ day & 8.3 & $\downarrow 0.8$ & 77.9 & & 59.9 & & $\uparrow 4.8$ \\
\hline
\end{tabular}

${ }^{*} P<0.05,{ }^{* *} P<0.001$ versus neutral protamine Hagedorn (NPH) insulin; ${ }^{\dagger} P=0.008$ versus morning insulin glargine.

A1c, glycosylated hemoglobin; IG, insulin glarine; IGb, bedtime IG; IGm, morning IG.

study ${ }^{16}$ specifically compared the effects of morning versus bedtime glargine administration. Doses of insulin in all trials were individually titrated to try and achieve prespecified glycemic targets (usually fasting). Trials were not blinded as the two insulins are easily distinguished: glargine is a clear solution, and NPH is cloudy. Treatment satisfaction was assessed in one study. ${ }^{15}$ Several studies have also investigated the effects of adding glargine or NPH to oral agents in suboptimally glycemic controlled T2DM patients. ${ }^{11,13-17}$

Fasting blood glucose (FBG) and A1c decreased significantly in all studies. Generally NPH insulin and insulin glargine were both equally effective in controlling glycemia. However, in some instances insulin glargine proved superior to NPH. Fritsche et al. ${ }^{16}$ studied three groups of subjects randomized to either morning insulin glargine, bedtime glargine, or bedtime NPH insulin: morning insulin glargine was significantly more effective in decreasing A1c than either bedtime glargine or NPH. These researchers also reported that significantly more patients in the morning insulin glargine group achieved an A1c of $7.5 \%$ or less (43\%) compared with bedtime NPH $(32 \%, P=0.017)$ or bedtime glargine $(33 \%$, $P=0.021)$. In addition, mean daily blood glucose levels were significantly lower with morning glargine than either bedtime NPH $(P<0.001)$ or bedtime glargine $(P=0.002)$. Massi Benedetti et al. ${ }^{18}$ also reported better glycemic control in a subgroup of overweight patients (body mass index $>28 \mathrm{~kg} / \mathrm{m}^{2}$ ) with insulin glargine compared with NPH.

Riddle et al. ${ }^{14}$ compared efficacy and safety of the addition of either NPH or glargine to two oral hypoglycemic agents in a large multicenter randomized trial with a target A1c of $7 \%$; both insulins were increased, during the study, according to a forced titration schedule. Although both treatment regimens were equally effective in lowering A1c (by 1.5\%) and fasting plasma glucose (FPG), 25\% more patients in the glargine group achieved this target without nocturnal hypoglycemia $(P<0.05)$. Mean yearly rates of symptomatic hypoglycemia were also significantly higher in the NPH group. The study also demonstrated that a significantly greater number of patients in the glargine group reached the target FPG of $\leq 5.55$ $\mathrm{mmol} / \mathrm{dL}$ and $\leq 6.66 \mathrm{mmol} / \mathrm{dL}$ compared with NPH: $22 \%$ and $33 \%$ with glargine versus 16 and $26 \%$ with $\mathrm{NPH}$, respectively $(P<0.03) .{ }^{14}$

These results were supported by two other multicenter, randomized trials that also determined that glargine resulted in less nocturnal hypoglycemia and improved pre- and postdinner glucose concentrations compared with $\mathrm{NPH}{ }^{11,13}$

Once-daily glargine has also been compared with twicedaily NPH (due to the latter's reduced time-action profile). ${ }^{20}$ The percentage of patients achieving target FPG was also numerically higher in the glargine group. Insulin doses at the end of the study were also lower in the insulin glargine group compared with NPH (62 vs. 72 U/day). Most studies have reported weight neutrality between the two insulins. However, two studies have demonstrated a $1 \mathrm{~kg}$ greater weight gain with NPH versus glargine. ${ }^{12,19}$

Treatment satisfaction has also been assessed by Eliaschewitz et al. ${ }^{15}$ Despite insulin glargine and NPH resulting in similar improvements of A1c and FBG, higher treatment satisfaction scores were obtained with insulin glargine compared with NPH. Linked to this finding, Eliaschewitz et al. ${ }^{15}$ also showed that patients who received insulin glargine were more likely to achieve A1c $\leq 7 \%$ without confirmed nocturnal 
Table 2. Randomized Trials Comparing Insulin Glargine with Premixed Insulins in Patients with Type 2 Diabetes Mellitus

\begin{tabular}{|c|c|c|c|c|c|c|c|c|c|c|c|}
\hline \multirow[b]{2}{*}{ Study } & \multirow[b]{2}{*}{$\begin{array}{l}\text { Duration } \\
\text { (weeks) }\end{array}$} & \multirow[b]{2}{*}{$\begin{array}{l}\text { Basal } \\
\text { insulin }\end{array}$} & \multirow[b]{2}{*}{$\mathrm{n}$} & \multirow[b]{2}{*}{$\begin{array}{l}\text { Mean daily } \\
\text { dose }\end{array}$} & \multirow{2}{*}{$\begin{array}{c}\text { Baseline } \\
\text { A1c } \\
(\%)\end{array}$} & \multirow{2}{*}{$\begin{array}{c}\text { A1c } \\
\text { change } \\
\text { from } \\
\text { baseline } \\
(\%)\end{array}$} & \multicolumn{2}{|c|}{ Hypoglycemic episodes } & \multicolumn{2}{|c|}{$\begin{array}{c}\text { Nocturnal hypoglycemic } \\
\text { episodes }\end{array}$} & \multirow{2}{*}{$\begin{array}{c}\text { Weight } \\
\text { gain } \\
(\mathrm{kg})\end{array}$} \\
\hline & & & & & & & $\begin{array}{c}\% \text { of } \\
\text { patients }\end{array}$ & $\begin{array}{l}\text { Events per } \\
\text { patient-year }\end{array}$ & $\begin{array}{c}\% \text { of } \\
\text { patients }\end{array}$ & $\begin{array}{l}\text { Events per } \\
\text { patient-year }\end{array}$ & \\
\hline \multirow[t]{2}{*}{ Malone et al. ${ }^{21}$} & 16 & IG & 53 & $0.57 \mathrm{U} / \mathrm{kg}$ & 8.7 & $\downarrow 0.9^{*}$ & & & 12 & & $\uparrow 1.6^{*}$ \\
\hline & & Pre & 52 & $0.62 \mathrm{U} / \mathrm{kg}$ & 8.7 & $\downarrow 1.3$ & & & 11 & & $\uparrow 2.3$ \\
\hline \multirow[t]{2}{*}{ Malone et al. ${ }^{22}$} & 16 & IG & 47 & $0.36 \mathrm{U} / \mathrm{kg}$ & 8.5 & $\downarrow 0.4^{* *}$ & & & & $0.3^{*}$ & $\uparrow 0.1^{*}$ \\
\hline & & Pre & 50 & $0.42 \mathrm{U} / \mathrm{kg}$ & 8.5 & $\downarrow 1$ & & & & 0.1 & $\uparrow 0.8$ \\
\hline \multirow[t]{2}{*}{ Raskin et al. ${ }^{23}$} & 28 & IG & 116 & $0.55 \mathrm{U} / \mathrm{kg}$ & 9.8 & $\downarrow 2.4^{*}$ & & $0.7^{*}$ & & & $\uparrow 3.5^{* *}$ \\
\hline & & Pre & 117 & $0.82 \mathrm{U} / \mathrm{kg}$ & 9.7 & $\downarrow 2.8$ & & 3.4 & & & $\uparrow 5.4$ \\
\hline \multirow[t]{2}{*}{ Strojek et al. ${ }^{24}$} & 26 & IG & 241 & $0.29 \mathrm{U} / \mathrm{kg}$ & 8.5 & $\downarrow 1.2$ & & $4.8^{*}$ & & $0.5^{*}$ & \\
\hline & & Pre & 239 & $0.32 \mathrm{U} / \mathrm{kg}$ & 8.5 & $\downarrow 1.4$ & & 6.5 & & 1.1 & \\
\hline \multirow[t]{2}{*}{ Ligthelm et al. ${ }^{25}$} & 24 & IG & 143 & $0.63 \mathrm{U} / \mathrm{kg}$ & & $\downarrow 1.2$ & & $3.4^{*}$ & & & $\uparrow 1.4^{* *}$ \\
\hline & & Pre & 137 & $1.19 \mathrm{U} / \mathrm{kg}$ & & $\downarrow 1.3$ & & 6.5 & & & $\uparrow 3.1$ \\
\hline \multirow[t]{2}{*}{ Kann et al. ${ }^{26}$} & 26 & $\mathrm{IG}$ & 127 & $0.39 \mathrm{U} / \mathrm{kg}$ & 8.9 & & $9^{*}$ & & & & $\uparrow 1.5$ \\
\hline & & Pre & 128 & $0.4 \mathrm{U} / \mathrm{kg}$ & 9.2 & & 20.3 & & & & $\uparrow 0.7$ \\
\hline \multirow[t]{2}{*}{ Janka et al. ${ }^{27}$} & 24 & IG & 177 & 28.2 U/day & 8.8 & $\downarrow 1.6^{* *}$ & 61.6 & $4.1^{* *}$ & & $0.5^{*}$ & $\uparrow 1.4$ \\
\hline & & Pre & 187 & $64.5 \mathrm{U} /$ day & 8.8 & $\downarrow 1.3$ & 67.2 & 9.9 & & 1 & $\uparrow 2.1$ \\
\hline
\end{tabular}

${ }^{*} P<0.05,{ }^{* *} P<0.001$ versus premixed insulin.

A1c, glycosylated hemoglobin; IG, insulin glargine; Pre, premixed insulin.

hypoglycemia than patients in the NPH group $(26.8 \%$ vs. $17.3 \%, P=0.014)$.

\section{Glargine Versus Premixed Insulin (Table 2)}

The effectiveness and safety of insulin glargine have also been compared with premixed insulins (both traditional and analog) in multicenter randomized trials lasting for 24-32 weeks. $^{21-27}$

Three trials demonstrated significantly greater reduction in A1c with twice-daily premixed analog insulins compared with insulin glargine. ${ }^{21-23}$ However, it should be noted that in all three studies the insulins were combined with only insulin sensitizers (metformin or pioglitazone). Thus there was no specific prandial coverage in the glargine groups. In the one study where glargine was combined with an oral insulin secretagogue, there was a greater reduction in A1c with the basal insulin as compared to the premixed insulin. ${ }^{27}$

Despite higher total insulin units in the premixed group, FBG levels were significantly lower in patients taking glargine, $^{21,22,25,27}$ and more patients in the glargine group achieved prespecified target FBG. ${ }^{21,22}$ As would be expected without mealtime coverage with glargine, most trials demonstrated lower postprandial blood glucose levels with premixed insulins compared with glargine. All studies consistently demonstrated higher rates of hypoglycemia with biphasic insulin compared with insulin glargine. Weight gain was also statistically significantly greater in patients taking premixed insulin..$^{21-23,25}$

\section{Glargine Versus Detemir (Table 3)}

Insulin glargine has been compared with insulin detemir in four large, multicenter, treat-to-target randomized trials. ${ }^{28-31}$ Each of these trials consisted of over 300 patients with type 2 $\mathrm{DM}$ and ranged in duration from 24 to 52 weeks. Studies consisted of either insulin-naive patients ${ }^{28,31}$ or patients already receiving insulin therapy. ${ }^{29,30}$ Baseline characteristics of the subjects were comparable between groups: body mass index, $\leq 40 \mathrm{~kg} / \mathrm{m}^{2}$; mean age, 57 years; mean FPG, $9.7 \mathrm{mmol} /$ $\mathrm{L}$; and A1c range, $7.0-11.0 \%$. Insulin glargine was administered once daily, and insulin detemir either once (and then increased to twice daily) or twice daily; doses were individually titrated. Because detemir is usually prescribed twice daily and has a separate titration target, it was difficult to blind the studies, and the trials were open-label. All trials showed noninferiority of detemir to glargine with respect to glycemic control. Detemir and glargine also resulted in similar improvement in A1c and FPG and similar risk of hypoglycemia. Risk of nocturnal hypoglycemia was also comparable. All four trials demonstrated higher withdrawal rate with insulin detemir due to minor adverse events (serious adverse events were similar between insulins). ${ }^{28-31}$ All four trials demonstrated that patients in the insulin glargine group gained more weight $(\sim 1 \mathrm{~kg})$ but also required significantly lower doses of insulin $(\sim 50 \%)$ compared with insulin detemir.

Thus the two basal insulin analogs, glargine and detemir, are equally effective in lowering A1c and have a comparable risk of hypoglycemia in a broad spectrum of patients with type 2 DM. Patients usually require twice-daily detemir, whereas glargine is prescribed as a once-daily regimen. Detemir doses are usually much higher than glargine doses. Detemir is associated with less weight gain than glargine, but it also requires higher doses; therefore, weight gain per dose would be comparable between the two insulin analogs. Moreover, lower weight gain in the detemir group was primarily reported in patients requiring once-daily dosage. However, the majority of patients will eventually require twice-daily doses of insulin detemir.

\section{Glargine Versus Glucagon-Like Peptide-1 Agonists (Table 4)}

Many physicians and type $2 \mathrm{DM}$ patients try to delay or even avoid initiation of insulin. The reasons are multifactorial 
Table 3. Randomized Trials Comparing Insulin Glargine with Insulin Detemir in Patients with Type 2 Diabetes Mellitus

\begin{tabular}{|c|c|c|c|c|c|c|c|c|c|c|c|}
\hline \multirow[b]{2}{*}{ Study } & \multirow[b]{2}{*}{$\begin{array}{l}\text { Duration } \\
\text { (weeks) }\end{array}$} & \multirow[b]{2}{*}{$\begin{array}{l}\text { Basal } \\
\text { insulin }\end{array}$} & \multirow[b]{2}{*}{$\mathrm{n}$} & \multirow{2}{*}{$\begin{array}{c}\text { Mean daily } \\
\text { dose }\end{array}$} & \multirow{2}{*}{$\begin{array}{c}\text { Baseline } \\
\text { A1c } \\
(\%)\end{array}$} & \multirow{2}{*}{$\begin{array}{c}\text { A1c } \\
\text { change } \\
\text { from } \\
\text { baseline } \\
(\%)\end{array}$} & \multicolumn{2}{|c|}{ Hypoglycemic episodes } & \multicolumn{2}{|c|}{$\begin{array}{c}\text { Nocturnal hypoglycemic } \\
\text { episodes }\end{array}$} & \multirow{2}{*}{$\begin{array}{l}\text { Weight } \\
\text { gain } \\
(\mathrm{kg})\end{array}$} \\
\hline & & & & & & & $\begin{array}{c}\% \text { of } \\
\text { patients }\end{array}$ & $\begin{array}{l}\text { Events per } \\
\text { patient-year }\end{array}$ & $\begin{array}{c}\% \text { of } \\
\text { patients }\end{array}$ & $\begin{array}{l}\text { Events per } \\
\text { patient-year }\end{array}$ & \\
\hline \multirow[t]{2}{*}{ Rosenstock et al. ${ }^{28}$} & 52 & IG & 252 & $0.44 \mathrm{U} / \mathrm{kg}$ & 8.6 & $\downarrow 1.5$ & 66 & 6.2 & 32 & 1.3 & $\uparrow 3.9^{*}$ \\
\hline & & ID & 231 & $0.78 \mathrm{U} / \mathrm{kg}$ & 8.6 & $\downarrow 1.5$ & 63 & 5.8 & 33 & 1.3 & $\uparrow 3.0$ \\
\hline \multirow[t]{2}{*}{ Raskin et al. ${ }^{29}$} & 26 & IG & 131 & $0.77 \mathrm{U} / \mathrm{kg}$ & 8.4 & $\downarrow 1.3$ & 74.8 & 17.9 & 42.7 & 3.3 & $\uparrow 2.7^{*}$ \\
\hline & & ID & 254 & $0.84 \mathrm{U} / \mathrm{kg}$ & 8.4 & $\downarrow 1.1$ & 76.2 & 19.3 & 46.1 & 4.2 & $\uparrow 1.2$ \\
\hline \multirow[t]{2}{*}{ Hollander et al. ${ }^{30}$} & 52 & IG & 105 & $0.59 \mathrm{U} / \mathrm{kg}$ & 8.8 & $\downarrow 1.8$ & 80 & 12.5 & 50.5 & 2.9 & $\uparrow 3.8^{*}$ \\
\hline & & ID & 214 & $0.82 \mathrm{U} / \mathrm{kg}$ & 8.6 & $\downarrow 1.4$ & 73.8 & 9.3 & 44.9 & 2.4 & $\uparrow 2.8$ \\
\hline \multirow[t]{2}{*}{ Swinnen et al. ${ }^{31}$} & 24 & $\mathrm{IG}$ & 478 & $43 \mathrm{U} /$ day & 8.7 & $\downarrow 1.5$ & 30 & & & & $\uparrow 1.4^{* *}$ \\
\hline & & ID & 486 & $76 \mathrm{U} /$ day & 8.7 & $\downarrow 1.5$ & 30 & & & & $\uparrow 0.6$ \\
\hline
\end{tabular}

${ }^{*} P<0.05,{ }^{* *} P<0.001$ versus insulin detemir (ID).

A1c, glycosylated hemoglobin; IG, insulin glargine.

but can include difficulties with insulin titration, risk of hypoglycemia, weight gain, inappropriate connotations of insulin therapy, and severity of disease.

Recently two glucagon-like peptide-1 (GLP-1) agonists (exenatide and liraglutide) have been approved for use in the United States. GLP-1 agonists can increase glucose-mediated insulin secretion and thus may be considered an alternative to basal or prandial insulin use in type $2 \mathrm{DM}$. However, this effect appears to be due to stimulation of existing $\beta$-cells rather than proliferation of new $\beta$-cells or increases in $\beta$-cell mass.

Clinical efficacy and safety of insulin glargine and GLP-1 agonists have been compared in four (three exenatide, one liraglutide) multicenter, randomized, controlled trials. ${ }^{32-35}$ Patients with type 2 DM poorly controlled with oral glucoselowering agents, with a mean age range of 54-60 years, mean body mass index range of $30-32 \mathrm{~kg} / \mathrm{m}^{2}$, and A1c range of $7.4-$ $9.95 \%$, were randomized to either insulin glargine or GLP-1 agonist, both in combination with metformin and/or sulfonylurea. Trials were not blinded as GLP-1 agonist doses are usually fixed and glargine needs to be titrated.

All three studies with exenatide reported similar results. Both regimens were equally effective in reducing $\mathrm{A} 1 \mathrm{c}(\sim 1 \%)$.
Heine et al. ${ }^{33}$ and Barnett et al. ${ }^{32}$ showed that similar proportions of exenatide- and insulin glargine-treated patients achieved an A1c $\leq 7 \%$. However, the mean A1c remained above the American Diabetes Association target of $\leq 7 \%$. At the end of the three studies, fasting plasma glucose was significantly lower in patients in the glargine group compared with exenatide. Barnett et al. ${ }^{32}$ demonstrated that $18.5 \%$ of glargine-treated patients achieved a fasting glucose $<5.6$ mmol/L compared with $5.5 \%$ of exenatide-treated patients $(P=0.032)$. Heine et al. ${ }^{33}$ reported similarly, with $22 \%$ versus $8.6 \%$ of patients achieving FBG $<5.6 \mathrm{mmol} / \mathrm{L}$ in the glargine and exenatide groups, respectively $(P<0.001)$. Bunck et al. ${ }^{34}$ also demonstrated greater reduction in FPG with glargine (-2.9 vs. $-1.6 \mathrm{mmol} / \mathrm{L}, P<0.0001)$.

Postprandial plasma glucose was significantly lower with exenatide compared with glargine in all three studies. It is interesting that premeal blood glucose concentrations, on the other hand, were lower in patients on glargine.

Heine et $\mathrm{al}^{33}$ reported that rates of symptomatic hypoglycemia were similar between treatments but that rates of nocturnal hypoglycemia were higher with glargine. Bunck et al. $^{34}$ also reported that confirmed hypoglycemia of $<3.3$

Table 4. Randomized Trials Comparing Insulin Glargine with Glucagon-Like Peptide-1 Agonists in Patients with Type 2 Diabetes Mellitus

\begin{tabular}{|c|c|c|c|c|c|c|c|c|c|c|c|}
\hline \multirow[b]{2}{*}{ Study } & \multirow[b]{2}{*}{$\begin{array}{l}\text { Duration } \\
\text { (weeks) }\end{array}$} & \multirow[b]{2}{*}{$\begin{array}{c}\text { Basal } \\
\text { insulin }\end{array}$} & \multirow[b]{2}{*}{$\mathrm{n}$} & \multirow[b]{2}{*}{$\begin{array}{l}\text { Mean daily } \\
\text { dose }\end{array}$} & \multirow{2}{*}{$\begin{array}{c}\text { Baseline } \\
\text { A1c } \\
(\%)\end{array}$} & \multirow{2}{*}{$\begin{array}{c}\text { A1c } \\
\text { change } \\
\text { from } \\
\text { baseline } \\
(\%)\end{array}$} & \multicolumn{2}{|c|}{ Hypoglycemic episodes } & \multicolumn{2}{|c|}{$\begin{array}{c}\text { Nocturnal hypoglycemic } \\
\text { episodes }\end{array}$} & \multirow{2}{*}{$\begin{array}{c}\text { Weight } \\
\text { gain } \\
(\mathrm{kg})\end{array}$} \\
\hline & & & & & & & $\begin{array}{c}\% \text { of } \\
\text { patients }\end{array}$ & $\begin{array}{l}\text { Events per } \\
\text { patient-year }\end{array}$ & $\begin{array}{c}\% \text { of } \\
\text { patients }\end{array}$ & $\begin{array}{l}\text { Events per } \\
\text { patient-year }\end{array}$ & \\
\hline \multirow[t]{2}{*}{ Barnett et al. ${ }^{32}$} & \multirow[t]{2}{*}{16} & IG & 70 & \multirow[t]{2}{*}{27.3 U/day } & & $\downarrow 1.4$ & 25.2 & & & & $\uparrow 0.6$ \\
\hline & & Ex & 68 & & & $\downarrow 1.4$ & 14.7 & & & & $\downarrow 1.6^{* *}$ \\
\hline \multirow[t]{2}{*}{ Heine et al. ${ }^{33}$} & \multirow[t]{2}{*}{26} & IG & 267 & \multirow[t]{2}{*}{$25 \mathrm{U} /$ day } & 8.3 & $\downarrow 1.1$ & & 6.3 & & 2.4 & $\uparrow 1.8$ \\
\hline & & Ex & 282 & & 8.2 & $\downarrow 1.1$ & & 7.3 & & 0.9 & $\downarrow 2.3^{* *}$ \\
\hline \multirow[t]{2}{*}{ Bunck et al. ${ }^{34}$} & \multirow[t]{2}{*}{52} & IG & 33 & \multirow[t]{2}{*}{$33.6 \mathrm{U} /$ day } & 7.4 & $\downarrow 0.7$ & & & & & $\uparrow 1^{* *}$ \\
\hline & & Ex & 36 & & 7.6 & $\downarrow 0.8$ & & & & & $\downarrow 3.6$ \\
\hline \multirow{3}{*}{$\begin{array}{l}\text { Russell-Jones } \\
\text { et al. }\end{array}$} & \multirow[t]{3}{*}{26} & $\mathrm{IG}$ & 234 & \multirow[t]{3}{*}{$24 \mathrm{U} /$ day } & 8.3 & $\downarrow 1.1^{*}$ & 28.9 & & & & $\uparrow 1.6$ \\
\hline & & Lir & 232 & & 8.3 & $\downarrow 1.3$ & 27.4 & & & & $\downarrow 1.8$ \\
\hline & & Lir $\mathrm{pl}$ & 115 & & 8.2 & $\downarrow 0.2^{* *}$ & 16.7 & & & & $\downarrow 0.4$ \\
\hline
\end{tabular}

${ }^{*} P<0.05,{ }^{* *} P<0.001$ versus liraglutide (Lir).

A1c, glycosylated hemoglobin; Ex, exenatide; GLP-1, glucagon-like peptide-1; IG, insulin glargine; Lir pl, Lir placebo. 
mmol/L was observed more often with glargine. Overall, Heine et al. ${ }^{33}$ reported fewer daytime hypoglycemic episodes with glargine, and Barnett et al. ${ }^{32}$ showed no differences between the two regimens.

There was a significant difference in weight during the above studies. Weight decreased by a mean of $\sim 2 \mathrm{~kg}$ in the exenatide group compared with a weight gain of $\sim 1 \mathrm{~kg}$ in the insulin glargine group $(P<0.001) .{ }^{32,33}$ Glargine in combination with metformin resulted in no change in body weight. ${ }^{32}$

Gastrointestinal adverse events (nausea, vomiting, and abdominal pain) were significantly higher in the exenatide group. Rates of other adverse events were comparable between the groups.

The fourth study, using the longer-acting GLP-1 agonist liraglutide, ${ }^{35}$ demonstrated a significant decrease in A1c levels compared with glargine $(1.3 \%$ vs. $1.1 \%)$. Weight loss and reduction of systolic blood pressure were also greater in the liraglutide group. Adverse events, particularly nausea, vomiting, and diarrhea, were also higher with liraglutide treatment.

Thus insulin glargine and exenatide (but not liraglutide) resulted in similar significant improvements in A1c. This was achieved because patients in the glargine group achieved lower FBG and had lower premeal blood glucose levels, whereas patients in the exenatide group had better postprandial plasma glucose control. Weight loss was consistently greater in the GLP-1 agonist groups. Risk of hypoglycemia was similar in the glargine and GLP-1 agonist groups. Gastrointestinal adverse events occurred more often in the GLP-1 agonist groups.

Several small studies ${ }^{36-38}$ and a large, multicenter, randomized trial ${ }^{39}$ have studied combination of a GLP-1 agonist with basal insulin. Generally these studies have demonstrated that addition of twice-daily exenatide to basal insulin glargine results in better glycemic control compared with basal insulin glargine alone. Lower A1c levels were achieved without increased risk of hypoglycemia or weight gain.

\section{Safety}

This topic is also discussed by Little et al. ${ }^{40}$ in this supplement.

\section{Hypoglycemia}

The UK Prospective Diabetes Study reported hypoglycemia and weight gain as key barriers to good glycemic control. A consistent finding of clinical studies has demonstrated a clear advantage of insulin glargine over NPH insulin in reducing hypoglycemia (Table 1). Most studies demonstrated a significantly lower risk of nocturnal hypoglycemia with glargine. Four trials ${ }^{11,14,15,19}$ also demonstrated significantly higher risk of overall hypoglycemia with NPH insulin compared with insulin glargine.

A recent meta-analysis of randomized controlled trials with a total of 3,181 patients with type 2 DM was conducted to evaluate the risk of hypoglycemia and confirmed the findings found in previous studies and meta-analyses. ${ }^{41}$ In general, insulin glargine has a significantly lower risk of hypoglycemia ( 50\%) compared with NPH. Severe hypoglycemia has been observed in $1.2 \%$ of patients studied in the insulin glargine group versus $2.3 \%$ of patients receiving $\mathrm{NPH}$ insulin $(P=0.0498)$. Symptomatic hypoglycemia with plasma glu- cose $<2.3 \mathrm{mmol} / \mathrm{L}$ and plasma glucose $<3.9 \mathrm{mmol} / \mathrm{L}$ were also more prevalent in the NPH group $(1.5 \%$ vs. $3.3 \%$ $[P=0.003]$ and $22.5 \%$ vs. $35.1 \%[P=0.009]$, respectively) compared with insulin glargine, respectively.

\section{Cancer}

Theoretically, any changes to the human insulin molecule could increase mitogenic effects. Thus human insulin analogs have been investigated for any potential mitogenic effects.

Insulin glargine has a similar affinity for the insulin receptor compared with human insulin using Chinese hamster ovary-human insulin receptor cells. A net effect of the structural changes of insulin glargine is a slightly increased disassociation rate from the insulin receptor compared with human insulin, which would decrease any mitogenic potency. ${ }^{42}$ B10Asp insulin, in comparison, has a much slower dissociation rate and a higher mitogenic effect. ${ }^{42,43}$

Stimulation of the insulin-like growth factor (IGF)-1 receptor, which is activated primarily by IGF-1 and secondarily by insulin, has been linked to greater mitogenic effects. ${ }^{42}$ The affinity of insulin glargine for the IGF insulin receptor has been studied in cancer cell lines, although at doses several log scales greater than treatment levels, to determine if the molecule has increased mitogenicity through this pathway. Some studies found no difference with human insulin, and some found a slightly higher (nonsignificant) affinity that does not reach endogenous IGF-1 binding. ${ }^{44,45}$

Kurtzhals et al. ${ }^{42}$ found a higher affinity for insulin glargine binding compared with human insulin in a study with human osteosarcoma Saos/B10 cells and attributed this increase to the additional arginines on the $\mathrm{C}$-terminus of the $\mathrm{B}$ chain and the A21 glycine substitution. In two more recent studies, Staiger et al. ${ }^{43}$ and Liefvendahl and Arnqvist ${ }^{45}$ determined, via measurement of $\left[{ }^{3} \mathrm{H}\right]$ thymidine incorporation in breast cancer $^{43,45}$ and osteosarcoma ${ }^{45}$ cell lines, that glargine has similar mitogenic effects compared with human insulin acting via the IGF-1 receptor.

The overall growth-promoting activity of insulin glargine was found to be similar to regular insulin in $\mathrm{H} 9$ myoblast $^{44}$ and breast cancer SKBR-3 and MCF-7 and osteosarcoma SaOS- $2^{45}$ cell lines. Thus mitogenic cell lines have been tested with insulin glargine at suprapharmacologic levels without finding significant increases in mitogenic potential.

A group of clinical studies assessing the cancer risk of insulin glargine were commissioned across Europe after a German observational study published in Diabetologia analyzed over 127,000 health insurance records and found an increased dosedependent risk of both malignant neoplasms and mortality with insulin glargine compared with human insulin treatment. ${ }^{46}$ The subsequent commissioned observational studies in Sweden, ${ }^{47}$ the United Kingdom, ${ }^{48}$ and Scotland ${ }^{49}$ produced mixed results. The Swedish study ${ }^{47}$ found an increased risk of breast cancer with glargine compared with several other types of insulin. The U.K. study ${ }^{48}$ found no increased risk of cancer with insulin analogs compared with human insulin. The Scottish study ${ }^{49}$ found no overall increase in cancer risk with insulin glargine when all patients taking glargine were grouped together. Thus the studies provided inconsistent results and lacked critical demographic information.

Relevant patient information such as insulin resistance, duration of diabetes, or body mass index, which of themselves 
are known to be risk factors for cancer, were not provided in these studies. ${ }^{46}$ The co-morbidities potentially present in insulin glargine patients, particularly those that are part of insulin resistance syndrome (high fasting glucose and obesity), have been independently linked to increased risks of certain cancers. ${ }^{50-56}$ Many studies have linked elevated blood glucose or A1c levels to colorectal cancers. ${ }^{57-63}$ In addition, elevated body mass index has been found to be associated with certain forms of endometrial cancers. ${ }^{64-67}$

None of the clinical studies linking insulin glargine to any type of cancer determined a causal relationship or explanation. Patients on insulin glargine may have any or all of these confounding factors or co-morbidities. Thus the lack of preclinical in vitro data and confounding clinical data preclude any causative association between insulin glargine and an increased cancer risk in patients with type $2 \mathrm{DM}$.

\section{Diabetic retinopathy}

Due to the finding that glargine has greater binding affinity for IGF-1 receptors compared with $\mathrm{NPH}$, there was some early concern that insulin glargine may be associated with increased progression of retinopathy. Davis et al. ${ }^{68}$ reported a higher percentage of patients treated with insulin glargine having a small increase in the Early Treatment Diabetic Retinopathy Study (ETDRS) retinopathy severity scale compared with $\mathrm{NPH}$ insulin (7\% vs. $2.7 \%$ ). However, these findings were not consistent, and a much larger trial ${ }^{69}$ with significant power did not find any difference between 5 years of treatment with glargine or NPH on diabetic retinopathy.

\section{Pregnancy}

Insulin glargine has category $\mathrm{C}$ approval for use in pregnancy in the United States. Theoretically the use of glargine should not present added mitogenic or teratogenic problems as the molecule does not cross the placenta. ${ }^{70}$ Several small studies and a meta-analysis have investigated both neonatal and maternal outcomes following glargine use in pregnancy. ${ }^{71-74}$ All have reported no increased fetal or maternal adverse events when glycemic control was obtained using glargine compared with NPH insulin.

\section{Cardiovascular diseases}

Two recent large, retrospective, studies demonstrated lower risk of acute myocardial infarction with insulin glargine compared with NPH or other long- or intermediate-acting insulins. Juhaeri et al. ${ }^{75}$ analyzed data from 65,619 patients with type 2 DM. Although acute myocardial infarction rates were found to be significantly lower with glargine, no difference was found between glargine and other intermediate-/ long-acting insulins in the rates of heart failure and stroke. Rhoads et al. ${ }^{76}$ also reported that initiation of basal insulin with insulin NPH was associated with greater risk of acute myocardial infarction compared with glargine.

\section{Immunogenicity}

Although the clinical significance is not clear, Yki-Järvinen et al. ${ }^{11}$ have demonstrated that insulin glargine is less immunogenic than NPH insulin. Similar results have also been demonstrated by Massi Benedetti et al. ${ }^{18}$ and Rosenstock et al. ${ }^{12}$ Both groups of investigators have demonstrated a greater drop in insulin antibody levels during insulin glargine therapy compared with NPH.

\section{Conclusions}

Glargine is the first basal insulin analog to have a 24-h action profile without prominent peaking effect in type $2 \mathrm{DM}$. Insulin glargine is comparable with NPH insulin, insulin detemir, and exenatide in reducing A1c levels. Some disadvantages include weight gain with glargine versus weight loss with GLP-1 agonists and more effective A1c reduction with biphasic insulins if insulin glargine is not combined with prandial coverage. Advantages of insulin glargine and detemir include lower incidence of hypoglycemia compared with $\mathrm{NPH}$ and biphasic insulins, significantly lower rates of gastrointestinal adverse events compared with GLP-1 agonists, and emerging data indicating a possible lower risk of acute myocardial infarction and lower immunogenicity compared with NPH.

\section{Author Disclosure Statement}

S.N.D. is a consultant and has received scientific grants from Sanofi-Aventis and Amylin Inc. M.S.H. and L.P. declare no competing interests.

\section{References}

1. Centers for Disease Control and Prevention. www.cdc.gov/ diabetes/pubs/pdf/ndfs_2007.pdf

2. Sanofi-Aventis. Lantus ${ }^{\circledR}$ Prescribing Information. Revised 2007. http://products.sanofi-aventis.us/lantus/lantus.pdf

3. Novo-Nordisk. Levemir ${ }^{\circledR}$ Prescribing Information. Revised 2009. www.levemirus.com/downloads/levemir-prescribinginformation.pdf

4. Kuerzel GU, Shukla U, Scholtz HE, Pretorius SG, Wessels DH, Venter C, Potgieter MA, Lang AM, Koose T, Bernhardt E: Biotransformation of insulin glargine after subcutaneous injection in healthy subjects. Curr Med Res Opin 2003;19:3440.

5. Luzio SD, Beck P, Owens DR: Comparison of the subcutaneous absorption of insulin glargine (Lantus) and NPH insulin in patients with type 2 diabetes. Horm Metab Res 2003;35:434-438.

6. Wang Z, Hedrington MS, Joy NG, Briscoe VJ, Richardson MA, Younk L, Nicholson W, Tate DB, Davis SN: Doseresponse effects of insulin glargine in type 2 diabetes. Diabetes Care 2010;33:1555-1560.

7. Hompesch M, Ocheltree SM, Wondmagegnehu ET, Morrow LA, Kollmeier AP, Campaigne BN, Jacober SJ: Pharmacokinetcis and pharmacodynamics of insulin lispro protamine suspension compared with insulin glargine and insulin detemir in type 2 diabetes. Curr Med Res Opin 2009;25: 2679-2687.

8. Luzio S, Dunseath G, Peter R, Pauvaday V, Owens DR: Comparison of the pharmacokinetics and pharmacodynamics of biphasic insulin aspart and insulin glargine in people with type 2 diabetes. Diabetologia 2006;49:1163-1168.

9. Scholtz HE, Pretorius SG, Wessels DH, Becker RHA: Pharmacokinetic and glucodynamic variability: assessment of insulin glargine, NPH insulin and insulin ultralente in healthy volunteers using a euglycaemic clamp technique. Diabetologia 2005;48:1988-1995.

10. Bolli GB, Andreoli AM, Lucidi P: Optimizing the replacement of basal insulin in type 1 diabetes mellitus: no longer 
an elusive goal in the post-NPH era. Diabetes Technol Ther 2011;13(Suppl 1):S-43-S-52.

11. Yki-Järvinen H, Dressler A, Ziemen M; HOE 901/300s Study Group: Less nocturnal hypoglycemia and better post-dinner glucose control with bedtime insulin glargine compared with bedtime NPH insulin during insulin combination therapy in type 2 diabetes. HOE 901/3002 Study Group. Diabetes Care 2000;23:1130-1136.

12. Rosenstock J, Schwartz S, Sherwyn L, Clark CM Jr, Park GD, Donley DW, Edwards MB: Basal insulin therapy in type 2 diabetes: 28-week comparison of insulin glargine (HOE 901) and NPH insulin. Diabetes Care 2001;24:631-636.

13. Yki-Järvinen $H$, Kauppinen-Mäkelin R, Tiikkainen M, Vähätalo M, Virtamo H, Nikkilä K, Tulokas T, Hulme S, Hardy K, McNulty S, Hänninen J, Levänen $\mathrm{H}$, Lahdenperä S, Lehtonen R, Ryysy L: Insulin glargine or NPH combined with metformin in type 2 diabetes: the LANMET study. Diabetologia 2006;49:442-451.

14. Riddle MC, Rosenstock J, Gerich J; Insulin Glargine 4002 Study Investigators: The treat-to-target trial: randomized addition of glargine or human NPH insulin to oral therapy of type 2 diabetic patients. Diabetes Care 2003;26:3080-3086.

15. Eliaschewitz FG, Calvo C, Valbuena H, Ruiz M, Aschner P, Villena J, Ramirez LA, Jimenez J; HOE 901/4013 LA Study Group: Therapy in type 2 diabetes: insulin glargine vs. NPH insulin both in combination with glimepiride. Arch Med Res 2006;37:495-501.

16. Fritsche A, Schweitzer MA, Häring HU; 4001 Study Group: Glimepiride combined with morning insulin glargine, bedtime neutral protamine Hagedorn insulin, or bedtime insulin glargine in patients with type 2 diabetes. A randomized, controlled trial. Ann Intern Med 2003;138:952-959.

17. HOE 901/2004 Study Investigators Group: Safety and efficacy of insulin glargine (HOE 901) versus NPH insulin in combination with oral treatment in Type 2 diabetic patients. Diabet Med 2003;20:545-551.

18. Massi Benedetti M, Humburg E, Dressler A, Ziemen M: A one-year, randomised, multicentre trial comparing insulin glargine with NPH insulin in combination with oral agents in patients with type 2 diabetes. Horm Metab Res 2003;35:189-196.

19. Fonseca V, Bell DS, Berger S, Thomson S, Mecca TE: A comparison of bedtime insulin glargine with bedtime neutral protamine Hagedorn insulin in patients with type 2 diabetes: subgroup analysis of patients taking once-daily insulin in a multicenter, randomized, parallel group study. Am J Med Sci 2004;328:274-280.

20. Rosenstock J, Fonseca V, McGill JB, Riddle M, Hallé JP, Hramiak I, Johnston P, Davis M: Similar progression of diabetic retinopathy with insulin glargine and neutral protamine Hagedorn (NPH) insulin in patients with type 2 diabetes: a long-term, randomised, open-label study. Diabetologia 2009;52:1778-1788.

21. Malone JK, Kerr LF, Campaigne BN, Sachson RA, Holcombe JH; Lispro Mixture-Glargine Study Group: Combined therapy with insulin lispro mix $75 / 25$ plus metformin or insulin glargine plus metformin: a 16-week, randomized, openlabel, crossover study in patients with type 2 diabetes beginning insulin therapy. Clin Ther 2004;26:2034-2044.

22. Malone JK, Bai S, Campaigne BN, Reviriego J, AugendreFerrante B: Twice-daily pre-mixed insulin rather than basal insulin therapy alone results in better overall glycaemic control in patients with type 2 diabetes. Diabet Med 2005;22:374-381.
23. Raskin $\mathrm{P}$, Allen E, Hollander $\mathrm{P}$, Lewin A, Gabbay RA, Hu P, Bode B, Garber A; INITIATE Study Group: Initiating insulin therapy in type 2 diabetes: a comparison of biphasic and basal insulin analogs. Diabetes Care 2005;28:260-265.

24. Strojek K, Shi C, Carey MA, Jacober SJ: Addition of insulin lispro protamine suspension or insulin glargine to oral type 2 diabetes regimens: a randomized trial. Diabetes Obes Metab 2010;12:916-922.

25. Ligthelm RJ, Gylvin T, Deluzio T, Raskin P: A comparison of twice-daily biphasic insulin aspart 70/30 and once-daily insulin glargine in persons with type 2 diabetes mellitus inadequately controlled on basal insulin and oral therapy: a randomized, open-label study. Endocr Pract 2011;17:41-50.

26. Kann PH, Wascher T, Zackova V, Moeller J, Medding J, Szocs A, Mokan M, Mrevlje F, Regulski M: Starting insulin therapy in type 2 diabetes: twice-daily biphasic insulin Aspart 30 plus metformin versus once-daily insulin glargine plus glimepiride. Exp Clin Endocrinol Diabetes 2006;114: 527-532.

27. Janka HU, Plewe G, Riddle MC, Kliebe-Frisch C, Schweitzer MA, Yki-Järvinen H: Comparison of basal insulin added to oral agents versus twice-daily premixed insulin as initial insulin therapy for type 2 diabetes. Diabetes Care 2005;28:254-259.

28. Rosenstock J, Davies M, Home PD, Larsen J, Koenen C, Schernthaner G: A randomised, 52-week, treat-to-target trial comparing insulin detemir with insulin glargine when administered as add-on to glucose-lowering drugs in insulinnaive people with type 2 diabetes. Diabetologia 2008;51: 408-416.

29. Raskin P, Gylvin T, Weng W, Chaykin L: Comparison of insulin detemir and insulin glargine using a basal-bolus regimen in a randomized, controlled clinical study in patients with type 2 diabetes. Diabetes Metab Res Rev 2009;25:542-548.

30. Hollander P, Cooper J, Bregnhøj J, Pedersen CB: A 52-week, multinational, open-label, parallel-group, noninferiority, treat-to-target trial comparing insulin detemir with insulin glargine in a basal-bolus regimen with mealtime insulin aspart in patients with type 2 diabetes. Clin Ther 2008;30:1976-1987.

31. Swinnen SG, Dain MP, Aronson R, Davies M, Gerstein HC, Pfeiffer AF, Snoek FJ, Devries JH, Hoekstra JB, Holleman F: A 24-week, randomized, treat-to-target trial comparing initiation of insulin glargine once-daily with insulin detemir twice-daily in patients with type 2 diabetes inadequately controlled on oral glucose-lowering drugs. Diabetes Care 2010;33:1176-1178.

32. Barnett AH, Burger J, Johns D, Brodows R, Kendall DM, Roberts A, Trautmann ME: Tolerability and efficacy of exenatide and titrated insulin glargine in adult patients with type 2 diabetes previously uncontrolled with metformin or a sulfonylurea: a multinational, randomized, open-label, twoperiod, crossover noninferiority trial. Clin Ther 2007;29: 2333-2348.

33. Heine RJ, Van Gaal LF, Johns D, Mihm MJ, Widel MH, Brodows RG; GWAA Study Group: Exenatide versus insulin glargine in patients with suboptimally controlled type 2 diabetes: a randomized trial. Ann Intern Med 2005;143: 559-569.

34. Bunck MC, Diamant M, Cornér A, Eliasson B, Malloy JL, Shaginian RM, Deng W, Kendall DM, Taskinen MR, Smith $\mathrm{U}$, Yki-Järvinen $\mathrm{H}$, Heine RJ: One-year treatment with exenatide improves beta-cell function, compared with insulin 
glargine, in metformin-treated type 2 diabetic patients: a randomized, controlled trial. Diabetes Care 2009;32:762-768.

35. Russell-Jones D, Vaag A, Schmitz O, Sethi BK, Lalic N, Antic S, Zdravkovic M, Ravn GM, Simó R; Liraglutide Effect and Action in Diabetes 5 (LEAD-5) met+SU Study Group: Liraglutide vs insulin glargine and placebo in combination with metformin and sulfonylurea therapy in type 2 diabetes mellitus (LEAD-5 met+SU): a randomised controlled trial. Diabetologia 2009;52:2046-2055.

36. Arnolds S, Dellweg S, Clair J, Dain MP, Nauck MA, Rave K, Kapitza C: Further improvement in postprandial glucose control with addition of exenatide or sitagliptin to combination therapy with insulin glargine and metformin: a proofof-concept study. Diabetes Care 2010;33:1509-1515.

37. Yoon NM, Cavaghan MK, Brunelle RL, Roach P: Exenatide added to insulin therapy: a retrospective review of clinical practice over two years in an academic endocrinology outpatient setting. Clin Ther 2009;31:1511-1523.

38. Sheffield CA, Kane MP, Busch RS, Bakst G, Abelseth JM, Hamilton RA: Safety and efficacy of exenatide in combination with insulin in patients with type 2 diabetes mellitus. Endocr Pract 2008;14:285-292.

39. Buse JB, Bergenstal RM, Glass LC, Heilmann CR, Lewis MS, Kwan AY, Hoogwerf BJ, Rosenstock J: Use of twice-daily exenatide in basal insulin-treated patients with type 2 diabetes: a randomized, controlled trial. Ann Intern Med 2011;154:103-112.

40. Little S, Shaw J, Home P: Hypoglycemia rates with basal insulin analogs. Diabetes Technol Ther 2011;13(Suppl 1): S-53-S-64.

41. Home PD, Fritsche A, Schinzel S, Massi-Benedetti M: Metaanalysis of individual patient data to assess the risk of hypoglycaemia in people with type 2 diabetes using NPH insulin or insulin glargine. Diabetes Obes Metab 2010;12: 772-779.

42. Kurtzhals P, Schaffer L, Sorensen A, Kristensen C, Jonassen I, Schmid C, Trub T: Correlations of receptor binding and metabolic and mitogenic potencies of insulin analogs designed for clinical use. Diabetes 2000;49:999-1005.

43. Staiger K, Hennige AM, Staiger H, Häring HU, Kellerer M: Comparison of the mitogenic potency of regular human insulin and its analogue glargine in normal and transformed human breast epithelial cells. Horm Metab Res 2007;39: 65-67.

44. Bähr M, Kolter T, Seipke G, Eckel J: Growth promoting and metabolic activity of the human insulin analogue [GlyA21,ArgB31,ArgB32]insulin (HOE901) in muscle cells. Eur J Pharmacol 1997;320:259-265.

45. Liefvendahl E, Arnqvist HJ: Mitogenic effect of the insulin analogue glargine in malignant cells in comparison with insulin and IGF-I. Horm Metab Res 2008;40:369-374.

46. Hemkens LG, Grouven U, Bender R, Gunster C, Gutschmidt S, Selke GW, Sawicki PT: Risk of malignancies in patients with diabetes treated with human insulin or insulin analogues: a cohort study. Diabetologia 2009;52:1732-1744.

47. Jonassen JM, Ljung R, Talback M, Haglund B, Gudbjornsdottir S, Steineck G: Insulin glargine use and short-term incidence of malignancies-a population-based follow-up study in Sweden. Diabetologia 2009;52:1745-1754.

48. Currie CJ, Poole CD, Gale EAM: The influence of glucoselowering therapies on cancer risk in type 2 diabetes. Diabetologia 2009;52:1766-1777.

49. Coulhoun HM; SDRN Epidemiology Group: Use of insulin glargine and cancer incidence in Scotland: a study from the
Scottish Diabetes Research Network Epidemiology. Diabetologia 2009;52:1755-1765.

50. Giovannucci E: The role of insulin resistance and hyperinsulinemia in cancer causation. Curr Med Chem Immunol Endocrinol Metab Agents 2005;5:53-60.

51. Schoen RE, Tangen CM, Kuller LH, Burke GL, Cushman M, Tracy RP, Dobs A, Savage PJ: Increased blood glucose and insulin, body size, and incident colorectal cancer. J Natl Cancer Inst 1999;91:1147-1154.

52. Nilsen TL, Vatten LJ: Prospective study of colorectal cancer risk and physical activity, diabetes, blood glucose and BMI: exploring the hyperinsulinaemia hypothesis. Br J Cancer 2001;84:417-422.

53. Saydah SH, Platz EA, Rifai N, Pollak MN, Brancati FL, Helzlsouer KJ: Association of markers of insulin and glucose control with subsequent colorectal cancer risk. Cancer Epidemiol Biomarkers Prev 2003;12:412-418.

54. Bostick RM, Potter JD, Kushi LH, Sellers TA, Steinmetz KA, McKenzie DR, Gapstur SM, Folsom AR: Sugar, meat and fat intake, and non-dietary risk factors for colon cancer incidence in Iowa women (United States). Cancer Causes Control 1994;5:38-52.

55. Russo A, Franceschi S, La Vecchia C, Dal Maso L, Montella M, Conti E, Ciacosa A, Falcini F, Negri E: Body size and colorectal-cancer risk. Int J Cancer 1998;78:161-165.

56. Zhang Y, Zhiwei L, Xinchun Y, Zhang X, Lu S, Chen X, Lu B: The association between metabolic abnormality and endometrial cancer: a large case-control study in China. Gynecol Oncol 1999;117:41-46.

57. Schoen RE, Tangen CM, Kuller LH, Burke GL, Cushman M, Tracy RP, Dobs A, Savage PJ: Increased blood glucose and insulin, body size, and incident colorectal cancer. J Natl Cancer Inst 1999;91:1147-1154.

58. Will JC, Galuska DA, Vinicor F, Calle EE: Colorectal cancer: another complication of diabetes mellitus? Am J Epidemiol 1998;147:816-825.

59. Hu FB, Manson JE, Liu S, Hunter D, Colditz GA, Michels KB, Speizer FE, Giovannucci E: Prospective study of adult onset diabetes mellitus (type 2) and risk of colorectal cancer in women. J Natl Cancer Inst 1999;91:542-547.

60. Nilsen TI, Vatten LJ: Prospective study of colorectal cancer risk and physical activity, diabetes, blood glucose and BMI: exploring the hyperinsulinaemia hypothesis. Br J Cancer 2001;84:417-422.

61. Khaw KT, Wareham N, Bingham S, Luben R, Welch A, Day $\mathrm{N}$ : Preliminary communication: glycated hemoglobin, diabetes, and incident colorectal cancer in men and women: a prospective analysis from the European Prospective Investigation into Cancer-Norfolk study. Cancer Epidemiol Biomarkers Prev 2004;13:915-919.

62. Higginbotham S, Zhang ZF, Lee IM, Cook NR, Giovannucci E, Buring JE, Liu S; Women's Health Study: Dietary glycemic load and risk of colorectal cancer in the Women's Health Study. J Natl Cancer Inst 2004;96:229-233.

63. Larsson SC, Orsini N, Wolk A: Diabetes mellitus and risk of colorectal cancer: a meta-analysis. J Natl Cancer Inst 2005;97:1679-1687.

64. Weiderpass E, Persson I, Adami HO, Magnusson C, Lindgren A, Baron JA: Body size in different periods of life, diabetes mellitus, hypertension, and risk of postmenopausal endometrial cancer (Sweden). Cancer Causes Control 2000;11:185-192.

65. Charneco E, Ortiz AP, Venegas-Ríos HL, Romaguera J, Umpierre S: Clinic-based case-control study of the 
association between body mass index and endometrial cancer in Puerto Rican women. P R Health Sci J 2010;29: 272-278.

66. Goodman MT, Hankin JH, Wilkens LR, Lyu LC, McDuffie K, Liu LQ, Kolonel LN: Diet, body size, physical activity, and the risk of endometrial cancer. Cancer Res 1997;57:50775085.

67. Levi F, La Vecchia C, Negri E, Parazzini F, Franceschi S: Body mass at different ages and subsequent endometrial cancer risk. Int J Cancer 1992;50:567-571.

68. Davis MD, Fisher MR, Gangnon RE, Barton F, Aiello LM, Chew EY, Ferris FL ${ }^{\text {rd }}$, Knatterud GL: Risk factors for highrisk proliferative diabetic retinopathy and severe visual loss: Early Treatment Diabetic Retinopathy Study report \#18. Invest Ophthalmol Vis Sci 1998;39:233-252.

69. Rosenstock J, Fonseca V, McGill JB, Riddle M, Halle J-P, Hramiak I, Johnston P, Davis M: Similar progression of diabetic retinopathy with insulin glargine and neutral protamine Hagedorn (NPH) insulin in patients with type 2 diabetes: a long-term, randomized, open-label study. Diabetologia 2009;52:1778-1788.

70. Pollex EK, Feig DS, Lubetsky A, Yip PM, Koren G: Insulin glargine safety in pregnancy: a transplacental transfer study. Diabetes Care 2010;33:29-33.

71. Price N, Bartlett C, Gillmer M: Use of insulin glargine during pregnancy: a case-control pilot study. BJOG 2007;114:453457.
72. Pöyhönen-Alho M, Rönnemaa T, Saltevo J, Ekblad U, Kaaja RJ: Use of insulin glargine during pregnancy. Acta Obstet Gynecol Scand 2007;86:1171-1174.

73. Gallen IW, Jaap A, Roland JM, Chirayath HH: Survey of glargine use in 115 pregnant women with Type 1 diabetes. Diabet Med 2008;25:165-169.

74. Pollex E, Moretti ME, Koren G, Feig DS: Safety of insulin glargine use in pregnancy: a systematic review and metaanalysis. Ann Pharmacother 2011;45:9-16.

75. Juhaeri J, Gao S, Dai WS: Incidence rates of heart failure, stroke, and acute myocardial infarction among Type 2 diabetic patients using insulin glargine and other insulin. Pharmacoepidemiol Drug Saf 2009;18:497-503.

76. Rhoads GG, Kosiborod M, Nesto RW, Fonseca VA, Lu SE, Zhang Q, Foody JM: Comparison of incidence of acute myocardial infarction in patients with type 2 diabetes mellitus following initiation of neutral protamine Hagedorn insulin versus insulin glargine. Am J Cardiol 2009;104:91-916.

Address correspondence to: Stephen N. Davis, MBBS, FRCP, FACP Department of Medicine University of Maryland School of Medicine 22 South Greene Street, Room N3W42 Baltimore, MD 21201

E-mail: sdavis@medicine.umaryland.edu 